\title{
菌床栽培ブナシメジ・ナメコ・エノキタケの一般成分と 無機質含量ならびに培地成分との関係
}

\author{
佐々木弘子*・青柳康夫**・春日敦子**・田中祐子** \\ 松沢睦子***川井英雄**
}

\author{
Relationships between Fruit Body Compositions and Substrates in \\ Bunashimeji [Hypsizigus marmoreus (Peck) Bigelow], Nameko \\ [Pholiota nameko (T. Ito) S. Ito Imai in Imai] and Enokitake \\ [Flammulina velutipes (Curt. : Fr.) Sing.] Mushrooms \\ Cultivated on Sawdust Substrate Beds
}

\author{
Hiroko SASAKI*, Yasuo AoYAGI**, Atsuko KASUGA**, Yuko TANAKA** \\ Mutsuko Matsuzawa** and Hideo Kawai* \\ * Kagawa Nutrition University, 3-9-21, Chiyoda, Sakado-shi, Saitama 350-02 \\ ** Kagawa Nutrition Junior College, 3-24-3, Komagome, Toshima-ku, Tokyo 170
}

\begin{abstract}
Ten samples of Bunashimeji [Hypsizigus marmoreus (Peck) Bigelow], fourteen samples of Nameko [Pholiota nameko (T. Ito) S. Ito et Imai in Imai] and eight samples of Enokitake [Flammulina velutipes (Curt. : Fr.) Sing.] mushroom cultivated on sawdust substrate beds were obtained together with their substrate beds, which were all of distinct origins. By analyzing proximate compositions and mineral contents in both these mushrooms and their substrate beds, effects of the sawdust substrate composition on the mushroom composition were examined. In Bunashimeji, Nameko and Enokitake mushrooms, the nitrogen content in their fruit body was not significantly related to that in the substrate. In Bunashimeji mushroom, concentration of minerals to the fruit body from the substrate was found in $\mathrm{K}$ (11.6 times), $\mathrm{Na}$ (9.73 times), $\mathrm{Zn}$ (1.81 times), $\mathrm{Cd}$ (4.30 times) and $\mathrm{Hg}$ (1.80 times), but a significant correlation between them was found only in $\mathrm{Na}$. Fe from the substrate was not concentrated in the fruit body, however, a significant correlation between the fruit body and its substrate was observed. In Nameko mushroom, concentration of minerals to the fruit body from the substrate was found in $\mathrm{K}$ ( 5.9 times), $\mathrm{Na}$ (2.31 times), $\mathrm{Mg}$ (1.52 times), $\mathrm{P}$ (4.52 times), $\mathrm{Cu}$ (1.69 times), $\mathrm{Zn}$ (4.02 times) and $\mathrm{Cd}$ (3.23 times). Ca from substrate was not concentrated in the fruit body, however, a significant correlation between the fruit body and its substrate was observed. In Enokitake mushroom, concentration of minerals from the substrate to the fruit body was found in $\mathrm{K}$ ( 3.13 times), $\mathrm{Zn}$ (1.76 times), $\mathrm{Cd}$ (1.89 times) and $\mathrm{Hg}(1.88$ times). Cu was not concentrated in the fruit body from the substrate, however a significant correlation between the fruit body and its substrate was observed.
\end{abstract}

(Received Jan. 11, 1994)

近年, キノコ類は自然食品として，また食物紻維を多

く含む健康食品として再認識されている. そのため需要
の增加に見合うように計画的生産が可能である菌床栽培 が、種々のキノコ類について行なわれてきている.しか

*女子栄養大学（干350-02 埼玉県坂戸市千代田 3-9-21）

* 女子栄養短期大学（干170 東京都豊島区駒込 3-24-3） 
し，菌床栽培の場合，種々の培地素材が使われる可能性 があり，また培地成分の重金属か子実体へ濃縮されると いう報告1,22)がみられるため，子実体とその培地成分と の関係を明らかにする必要がある。

既に我々は原木栽培および菌床栽培のシイタケ [Lentinus edodes (Berk.) Sing.] 子実体ならびにその菌 床培地の成分との相関3)，ヒラタヶ [Pleurotus ostreatus (Jacq. ex Fr.) Quél.] よびマイタヶ [Grifora frondosa (Dicks. : Fr.) S.F. Gray]の子実体とその菌床培地の成 分との相関)について報告したが，今回はシイタケ，ヒ ラタケ，マイタケと同様に生産地および生産者などが明 らかな菌床栽培ブナシメシ [Hypsizigus marmoreus (Peck) Bigelow], ナメ [Pholiota nameko (T. Ito) S. Ito et Imai in Imai]，エノキタヶ [Flammulina velutipes (Curt. : Fr.) Sing.] の子実体と培地の一般成分および 無機質含量を定量し，培地成分と子実体との相関につい て恰討したので報告する.

\section{実 験 方 法}

\section{1. 試料の収集}

ブナシメジは長野，茨城，奈良の生産者より合計 10 件，約 $2 \mathrm{~kg}$ ずっ収集した。 ナメコは山形，宮城，新潟， 長野の生産者より, 合計 14 件, 約 $1.5 \mathrm{~kg}$ ずつ収集した。 エノキタケは長野, 新䳆の生産者より合計 8 件, 約 1.5 $\mathrm{kg}$ ずつ収集した。

培地は子実体を収集したものと同一ロットで, 植菌直 後のあの各 3〜5 個 $(1.3 \mathrm{~kg} \sim 3.1 \mathrm{~kg})$ を入手した.なお， 各子実体は出荷規格にあった標準品，すなわちプナシメ ジは茎の長さ $6 \sim 8 \mathrm{~cm}$, 径 $3 \mathrm{~cm}$ 内外のあの, ナメ コは萃の径 $28 \mathrm{~mm}$ 末満のもの,エノキタケは茎の長さ 13 14 cm, 傘の径約 $1 \mathrm{~cm}$ のあのを収集した. しかし一 般の生産者からの試料の収集であったため, 種菌の種類 および菌床の樹種は特定出来なかった。

各生産者により採取された子実体ならびに培地は，た だちにクール便にて本学に送付され, 以後の操作は前 報)に従った。

\section{2. 分析方法}

一般成分の分析は，四訂日本食品標準成分表記載の常 法5゙により行なった．ただし，脂質についてはンックス レー抽出によった。 タンパク質は子実体と培地の窒素量 を比較するためケルダール登素量として示した，培地に ついては，一般成分のうちケルダール窒素と灰分につい てのみ测定した。

無機質のうちカルシゥム, マグネシゥム, リン, 鉄,
銅，亚鉛，マンガンの測定は乾式灰化後，誘導結合プラ ズマ発光分光分析計 (ICP)により行なった. カリウムと ナトリゥムは $1 \%$ 塩酸を用いて抽出し，炎光光度計によ り測定した．水銀は水銀分析用加熱気化装固により測定 した．カドミウムの分析は硝酸-過塩素酸にて湿式灰化 後，原子吸光分析計により行なった。

分析結果はそれぞれ平均値士標準偏差として示した。

\section{結果および考察}

\section{1. 菌床栽培ブナシメジ成分と培地成分の関係}

ブナシメジの子実体と培地の一般成分値を Fig. 1 に 示した.

水分以外の成分については無水物基準換算値として示 した. 四訂日本食品標準成分表 ${ }^{5}$ （以下，成分表之略）に 比較して脂質は約 $1 / 3$ 量の低值を示したが，その他の一 般成分値はほぼ同じ値を示し，倉㳯ら年の値ともほとん ど同じ值を示した，今回分析に供した子実体は生産年 度, 生産地および生産者が違っても，成分にほとんど差 がみられなかった。これは栽培方法がシステム化されて

(A)
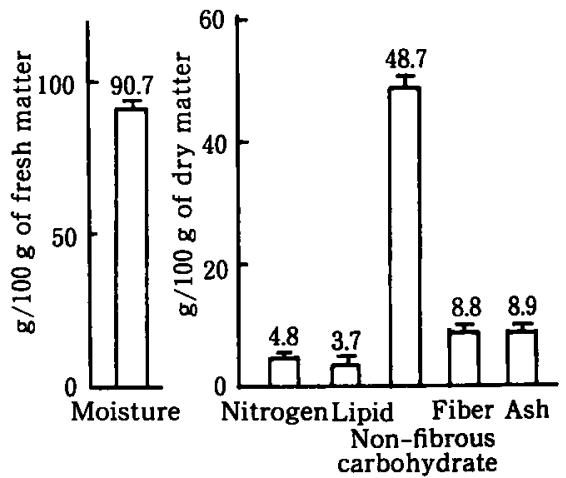

(B)

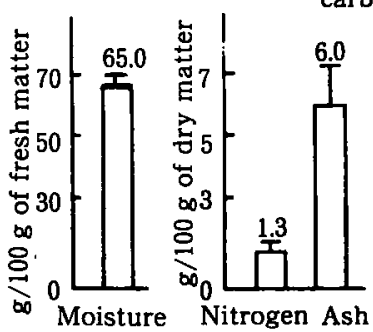

Fig. 1 Proximate compositions of Bunashimeji [Hysyizigus marmoreus (Peck) Bigelow] mushroom and sawdust substrate bed

Ten pairs of Bunashimeji mushroom (A) and its sawdust substrate bed (B) were analyzed.

Values are means $\pm S D$. 
いることなどが一因と考えられた。なお，子実体と培地 の窒素量間ならびに灰分量間には相関は認められなかっ た. 子実体中の無機質含量のナトリウムを成分表 ${ }^{5)}$ と比 较すると約 4 倍高い值を示し，マンガンは数野ら の値 に比較し 1.5 倍高く，銅は約 $1 / 2$ 量と低かった.

子実体と培地の無機質含量の比較を Fig. 2 に示した. カリウムは $11.66 \pm 6.06$ 倍, 亜鉛は $1.81 \pm 1.02$ 倍, カドミ ウムは $4.30 \pm 1.87$ 倍, 水銀は $1.80 \pm 0.13$ 倍の培地成分か

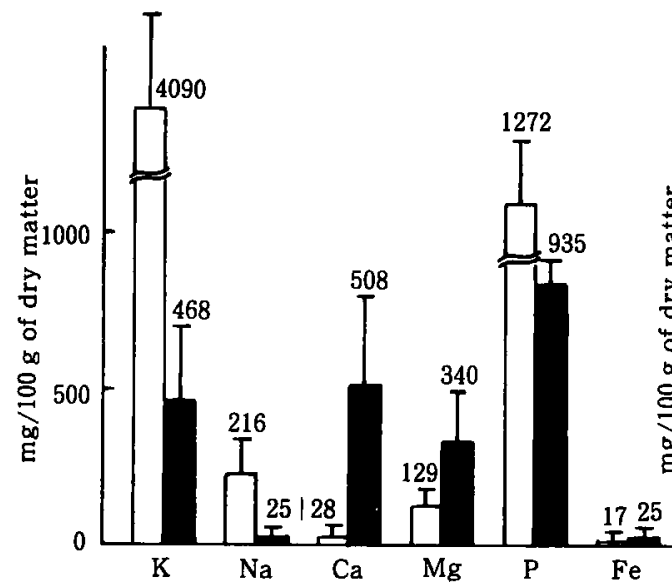

ら子実体への濃縮がみられたが, 培地濃度との間には相 関は認められなかった。 ナトリウムは $9.73 \pm 3.34$ 倍の濃 樎がみられ, 相関係数が 0.7577 の有意 $(\mathrm{p}<0.05)$ な相関 がみられた (Fig. 3). 鉄は培地からの濃縮はみられな かったが, 相関係数が 0.8833 の有意 $(\mathrm{p}<0.01)$ な相関が みられた (Fig. 4). カリウムは濃縮割合が大きいが変動 係数も高いため, 試料による差す大きいあのと考えられ た。 また有害とされるカドミウムは約 5 倍の濃縮がみら

Fig. 2 Mineral contents of Bunashimeji [Hypsizigus marmoreus (Peck) Bigelow] mushroom and sawdust substrate bed

Values are means $\pm S D$. $(n=10)$

White bar : Fruit body

Black bar : Sawdust substrate bed

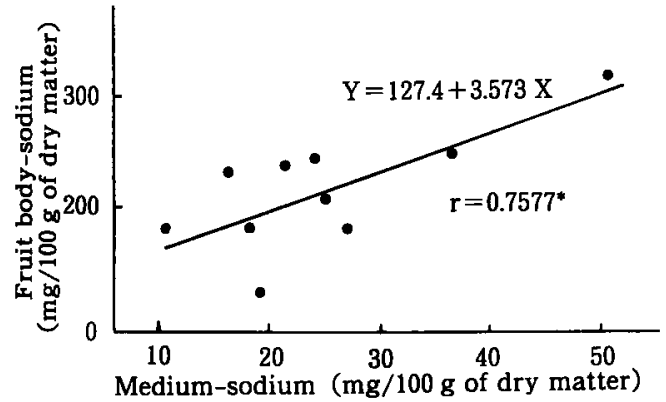

Fig. 3 A relationship in sodium content between fruit body and sawdust substrate bed

Ten pairs of Bunashimeji [Hypsizigus marmoreus (Peck) Bigelow] mushroom and its sawdust substrate bed were analyzed.

: $\mathrm{p}<0.05$

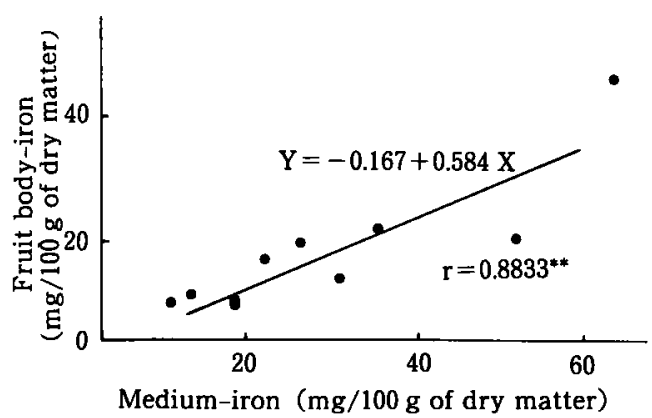

Fig. 4 A relationship in iron content between fruit body and sawdust substrate bed

Ten pairs of Bunashimeji [Hypsizibus marmoreus (Peck) Bigelow] mushroom and its sawdust substrate bed were analyzed.

** $: \mathrm{p}<0.01$ 
(A)
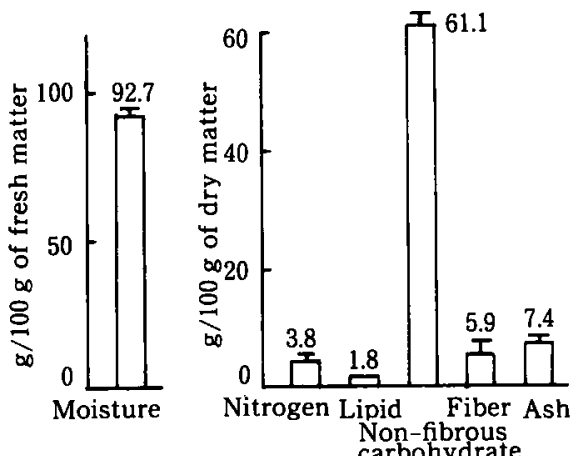

(B)
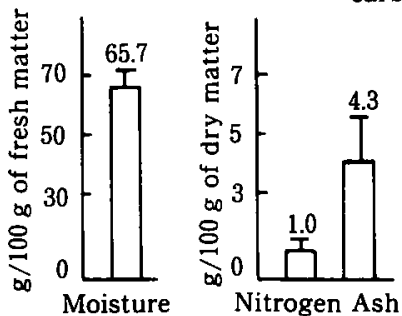

Fig. 5 Proximate compositions of Nameko [Pholiota nameko (T.Ito) S. Ito et Imai in Imai] mushroom and sawdust substate bed

Fourteen pairs of Nameko mushroom (A) and its sawdust substrate bed (B) were analyzed. Values are means $\pm S D$.
れたが，変動係数も大きいため，個体差による影繁が大 きく，量においてあ安全上特に問題になる量㝵ではない ことが確かめられた。

TYLER $^{9)}$ は野生キノコ 130 種，200 個体の子実体には $0.1 \sim 299 \mu \mathrm{g} / \mathrm{g}$, 平均 $1.4 \mu \mathrm{g} / \mathrm{g}$ のカドミウムが存在し, 子実体とキノコの生えていた土壤中のカドミゥム濃度と の間に相関はみられないと報告している. また特にハラ タケ属のキノコでは高濃度に存在し，特異的に濃缩され るため, 菌系の生長に必須の元素であると示唆してい る. 菌床栽培の子実体の值は野生キノコの平均値の $1 / 3$ 量であり，濃縮率も低いため，ブナシメジでは子実体の 中でのカドミゥムの生理的役割を推察するのは難しいと 思われた. 堀越 ${ }^{(0)}$ の総説では野生キノコ中の平均水銀濃 度は約 $140 \mu \mathrm{g} / 100 \mathrm{~g}$ （乾燥重量当り）でキシメジ科に餥 度の高いものがあるとしている，菌床载培子実体中では $2 \pm 1.4 \mu \mathrm{g} / 100 \mathrm{~g}$ とかなり低い值であり，また濃縮率も 小さいことから，菌床栽培キノコでは安全上問題はない と考えられた。

2. 菌床栽培ナメコ成分と培地成分の関係

ナメコの子寒体および培地の一般成分值を Fig. 5 に 示した．子実体は成分表 ${ }^{5)}$ に比較して死分は約 1.5 倍量 と多く，脂質は約 $1 / 2$ 量と低い值であった。 なお子実体 と培地の窒素量間ならびに灰分間には相関は認められな かった。

子実体の無機質は成分表 ${ }^{5)}$ に比較してカルシウムは約 $1 / 3$ 量, ナトリウムは約 $1 / 2$ 量であった．銅は日本食品
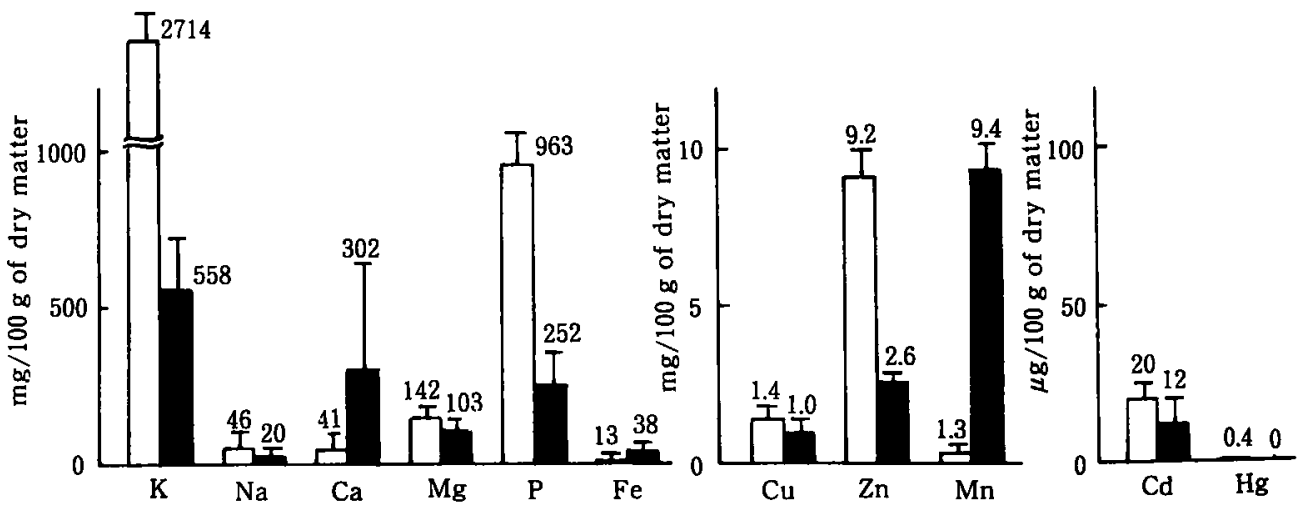

Fig. 6 Mineral contents of Nameko [Pholiota nameko (T. Ito) S. Ito et Imai in Imai] mushroom and sawdust substrate bed

Value are means $\pm S D$.

White bar : Fruit body

Black bar : Sawdust substrate bed 
無機質成分表 ${ }^{(1)}$ に比較すると約 $1 / 2$ 量であった。

子実体と培地の無機質含量の比較を Fig. 6 に示した。 カリウムは $5.39 \pm 2.38$ 倍, ナトリウムは $2.31 \pm 1.16$ 倍, マグネシウムは $1.52 \pm 0.60$ 倍, リンは $4.52 \pm 2.12$ 倍, 銅 は $1.69 \pm 1.04$ 倍, 垔鉛は $4.02 \pm 2.43$ 倍, カドミウムは $3.23 \pm 4.16$ 倍の子実体への浱縮がみられた. 培地浱度と の間には相関は認められなかった。カカルシウムは培地か らの㐮縮はみられなかったが，相関係数 0.6088 の有意 (p<0.01）な相関がみられた（Fig. 7).

カドミゥム以外で濃縮されている無機質は，濃縮割合 が約 1.7〜 5.4 倍, 変動係数が 39〜60 の範囲であり, ブナ シメシと比べ, 低い值を示した. カドミウムは約 3 倍濃 緶されたが，変動係数が 129 とかなり大きく，個体差の 影怔大きいことが考えられた。 さらに量においてすブ ナシメシ同様，安全上特に問題となる量 ${ }^{8)}$ ではないこと 加確認された. 水銀は子実体に $0.4 \pm 0.63 \mu \mathrm{g} / 100 \mathrm{~g}$ とご く少量存在したが, 培地中には検出限界以下であった. 场越 ${ }^{10)}$ による野生キノコの平均值の $1 / 300$ 量と非常に 少ないことが確かめられた。

\section{3. 菌床栽培エノキタケ成分と培地成分の関係}

エノキタケの子実体および培地の一般成分值を Fig. 8 に示した. 子夷体の粗織維は成分表5)の 1.2 倍量を示し たが，他の成分はほとんど同じレベルであった，子実体 と培地の窒素量間ならびに灰分量間に相関は認められな かった.

川井ら ${ }^{12)}$ の報告と比較すると,ナトリゥムは約 $1 / 4$ 量 であり，亜鉛は 1.5 倍量であった，他の無機質はほぼ同 じ值であった． マグネシウム，亜鉛は日本食品無機質成 分表 ${ }^{12)}$ とほぼ同じ值であった. エノキタヶの栽培方法は 確立されたものであり，生産者，生産場所などの違いに よる影繁はほとんど無いるのと推察された，子実体と培 地の無機質含量を Fig. 9 に示した. カリウムは $3.13 \pm$ 0.25 倍，亜鉛は $1.76 \pm 1.15$ 倍，カドミウムは $1.89 \pm 3.07$ 倍、水銀は $1.88 \pm 0.78$ 倍の培地から子実体への濃樎がみ られたが，培地中のこれら無機質濃度との間には相関は 認められなかった。銅は培地からの濃縮はみられなかっ たが, 相関係数 0.7852 の有意（p<0.05）な相関がみられ た (Fig. 10).カリウムの湌縮は変動係数 8.0 とバラッキ 功小く, 亜鈶, 水銀は変動係数 41,65 とややバラッキ がみられた，カドミゥムは約 2 倍浱縮されているが，変 動係数 162 とかなりバラッキがみられ，個体差があるも のと考えら机た．子実体中のカドミゥム量においてはフ ナシメジ,ナメコと同様, 安全上特に問題となる量 ${ }^{8)}$ はないことが確認された. 子寒体と培地中の水銀はキシ
メジ科のブナシメシ，エノキタケではほとんど同じ量で あった.

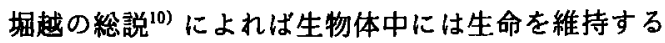

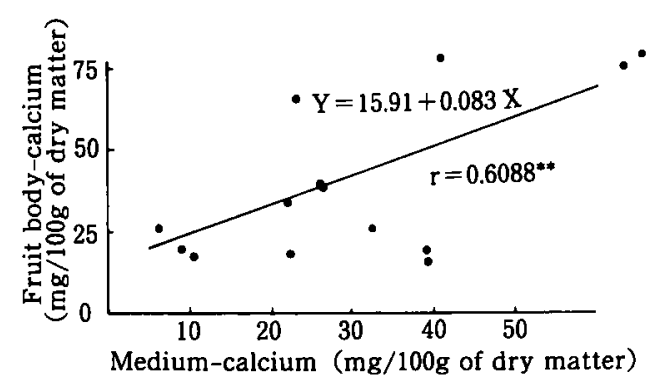

Fig. 7 A relationship in calcium content between fruit body and sawdust substrate bed

Fourteen pairs of Nameko [Pholiota nameko (T. Ito) S. Ito et Imai in Imai] mushroom and its sawdust substrate bed were analyzed. ** : $\mathrm{p}<0.01$

(A)
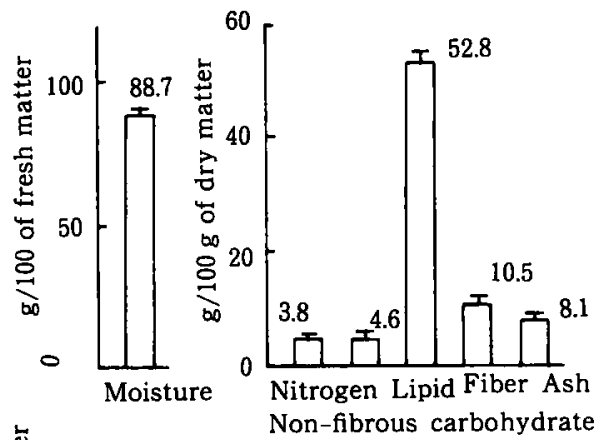

(B)
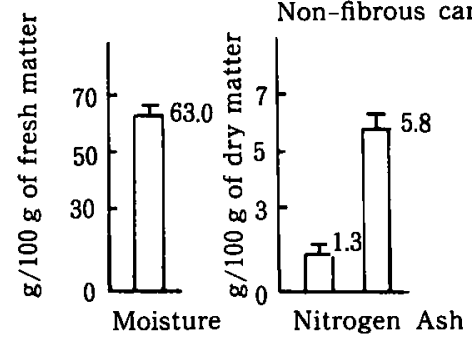

Fig. 8 Proximate composition of Enokitake [Flammulina velutipes (Curt.: Fr.) Sing.] mushroom and sawdust substrate bed

Eight pairs of Enokitake mushroom (A) and its sawdust substrate bed (B) were analyzed. Values are means $\pm \mathrm{SD}$. 

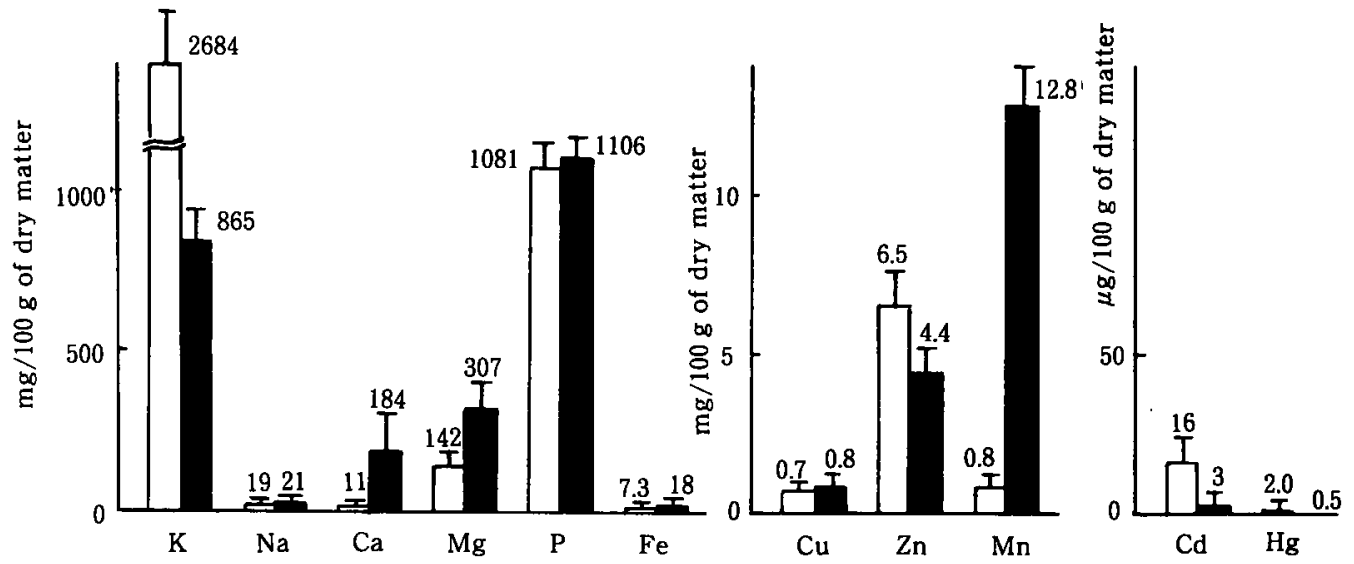

Fig. 9 Mineral contents of Enokitake [Flammulina velutipes (Curt. : Fr.) Sing.] mushroom and sawdust substrate bed

Values are means $\pm S D$.

White bar : Fruit body

Black bar : Sawdust substrate bed

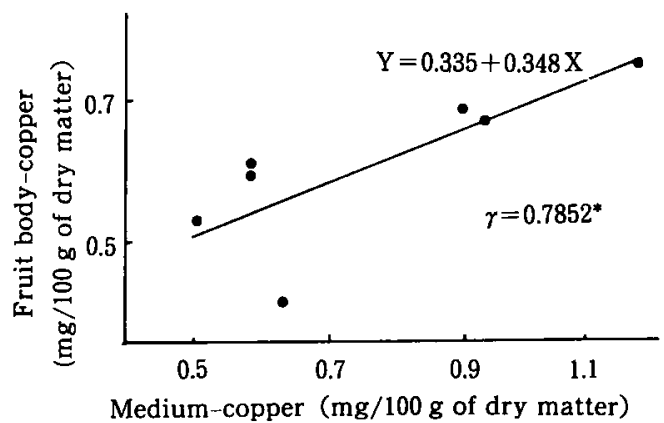

Fig. 10 A relationship in copper content between fruit body and sawdust substrate bed

Eight pairs of Enokitake [Flammulina velutipes (Curt. : Fr.) Sing.] mushroom and its sawdust substrate bed were analyzed.

$*: p<0.05$

のに必要な必須金属としてカリウム,ナトリゥム, マグ ネシウム,カルシウム, 鉄など 14 種類の元素が知られて いるが, キノコ類のこれら必須金属濃度の頻度分布パ ターンは正規分布に近いものであり，特に高濃度に濃縮 するキノコは見いだされていないとしている. 今回分析 したキシメジ科のブナシメジとエノキタケの必須金属の 濃樎はカリウム, ナトリゥムで濃縮率に大きな差がみら
れたが，その他の元素はほぼ同じ濃縮率であった．モェ ギタケ科であるナメコはキシメジ科のブナシメジ，エノ キタヶとは元素の濃縮率はかなり違ったパターンを示し た。

要 約

菌床栽培のプナシメジ 10 試料, ナメコ 14 試料, エノ キタケ 8 試料の子実体とその菌床培地の一般成分と無機 質含量を测定し，菌床成分の子実体への影传にっいて検 討した。

(1) ブナシメジ,ナメコ,エノキタケいずれの場合す, 培地窒素量と子実体タンパク質量との間に有意な相関は みられなかった。

(2) ブナシメジでは菌床から子実体への無機質の濃缩

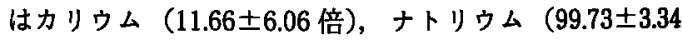

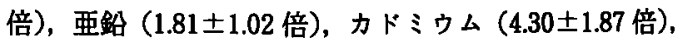
水銀 $(1.80 \pm 0.13$ 倍) でみられた。培地と子実体との相関 は濃縮がみられたナトリウム $(\mathrm{P}<0.05)$ ，濃縮がみられ なかった鉄 $(P<0.01)$ で有意が認められた。

(3) ナメコでは菌床から子実体への無機質の濃縮はカ

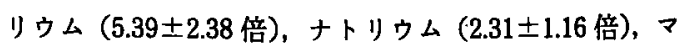

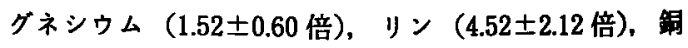

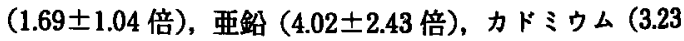
士4.16 倍) でみられた。培地と子実体との相関は浱樎が みられなかったカルシゥム $(\mathrm{P}<0.05)$ で有意が認められ 
た.

(4) エノキタケでは菌床から子害体への無機質の濃縮 はカリゥム (3.13 \pm 0.25 倍), 亜鈆 $(1.76 \pm 1.15$ 倍), カド ミウム $(1.89 \pm 3.07$ 倍)，水銀 (1.88土0.78倍) でみられ た. 培地と子実体との相関は䍚縮がみられなかった銅 （P<0.05）でのみ有意が認められた。

本研究を遂行するにあたり，終始ご指導を睗りました 女子栄養大学教授营原龍幸博士に対し，深く感謝の意を 表します。また試料の収集にご協力くださいました日本 特用林産振興会にお礼申し上げます。

\section{文献}

1）大江章夫・杉谷 折 - 山田不二造 : 食衛誌, 22 , 345 (1981).

2）安井明美・堤 忠一・高橋政則・森 健：日食工 誌, 35, 160 (1988).

3）青柳康夫 · 春日敦子 ·佐々木弘子・松沢睦子 ·伝
川祐子 - 川井英雄 : 日食工誌，40，771（1993）。

4）川井英雄・松沢睦子 - 伝川祐子 - 佐々木弘子 - 春 日敦子・青柳康夫 : 日食工誌, 41, 419 (1994).

5）科学技術庁資源調査会：四訂日本食品標準成分 表, 科学技術庁資源調查会編，(大蔵省印刷局，東 京) p. 20 28, p. 258 262 (1982).

6）倉澤新一－菅原龍幸・林 淳三：日食工誌，29, 400 (1982).

7）数野千恵子 · 三浦 洋：日食工誌，31，649 (1984).

8）厚生省「カドミウムによる環境污染暫定対策」 1969 年 3 月, 1970 年 7 月

9) G. TyLER : Trans. Br. Mycol. Soc. 74, 41 (1980).

10）堀越孝雄：植物之自然, 16, 17 (1982).

11）科学技術庁資源調查会：日本食品無機質成分表 (マグネシゥム，覀鈶，銅），科学技術庁資源調查 会編,（大藏省印刷局, 東京) p. 62 (1991).

12）川井英雄 - 营原龍幸 - 角屋敷佳代子 - 青柳康夫 · 細貝祐太郎：日食工誌，33，250（1986）. (平成 6 年 1 月 11 日受理) 